\title{
Алкогольна септальна абляція у пацієнтів 3 гіпертрофічною кардіоміопатією та ожирінням
}

\author{
Руденко К. В. ${ }^{1}$, Невмержицька Л. О. ${ }^{1}$, Дудник О. Ю. ${ }^{1}$, Фанта С. М. ${ }^{1}$, Маланюк В. І. ${ }^{2}$, \\ Лазоришинець В. В. ${ }^{1}$ \\ ${ }^{1}$ ДУ «Національний інститут серцево-судинної хірургії імені М. М. Амосова НАМН України», м. Київ, Україна \\ ${ }^{2}$ Національний військово-медичний клінічний центр «Головний військовий клінічний госпіталь», м. Київ, Україна
}

\begin{abstract}
Резюме. У статті представлений огляд літератури та аналіз власного досвіду лікування пацієнтів з гіпертрофічною кардіоміопатією (ГКМП) та ожирінням. Ожиріння є значущим фактором ризику розвитку серцево-судинних захворювань та їх перебігу. Хоча в літературі описаний «парадокс ожиріння», показано, що він відображає зворотну причинність: втрата ваги є наслідком тяжкої хвороби, а не її причиною.

Доведено, що ожиріння в пацієнтів із ГКМП асоціюється з більшою масою лівого шлуночка (ЛШ), тяжчими симптомами, нижчою толерантністю до фізичних навантажень і лабільною обструктивною гемодинамікою. Нами був досліджений вплив ожиріння на результати проведення алкогольної септальної абляції (АСА) в пацієнтів з ГКМП.

Було показано, що АСА в пацієнтів з ГКМП та ожирінням у більшості випадків здатна покращити клінічний перебіг захворювання (зменшити симптоми, покращити функціональний клас), при цьому анатомічні та гемодинамічні результати проведеної процедури в пацієнтів з ожирінням та з нормальним індексом маси тіла не відрізнялись у безпосередній період спостережень. Алкогольна септальна абляція рекомендована як метод вибору в пацієнтів з гіпертрофічною кардіоміопатією та ожирінням.
\end{abstract}

Ключові слова: гіпертрофічна кардіоміопатія, ожиріння, парадокс ожиріння, алкогольна септальна абляція.

Вступ. Гіпертрофічна кардіоміопатія (ГКМП) - це найпоширеніше генетичне серцево-судинне захворювання, що уражує приблизно 1 на 500 осіб у загальній популяції та проявляється у вигляді лівошлуночкової гіпертрофії, життєво загрозливих аритмій і серцевої недостатності. Ожиріння стало найбільш переважаючим хронічним медичним станом у західних країнах і справляє найбільший вплив на розвиток серцево-судинних захворювань. Незважаючи на велику кількість доказів, що свідчать на користь зв'язку між ожирінням і лівошлуночковою гіпертрофією, дотепер досить мало досліджень щодо потенційного впливу ожиріння на лівошлуночкову гіпертрофію при ГКМП [1].

Відповідно до визначення ВООЗ від 2000 року, ожирінням прийнято вважати захворювання, при якому надлишковий накопичений жир у тілі несприятливо впливає на стан здоров'я, призводячи до зменшення середньої тривалості життя та/або збільшення проблем зі здоров'ям. Людину вважають хворою на ожиріння, якщо індекс маси тіла (IMT), показник, який можна обрахувати, розділивши вагу людини у кілограмах на зведений у квадрат зріст людини в метрах, перевищує $30 \kappa \Gamma / \mathrm{M}^{2}$.

Останні рекомендації щодо ведення пацієнтів 3 ГКМП наполягають на жорсткій модифікації загаль- них факторів серцево-судинного ризику, включаючи ожиріння [2]. Проте, незважаючи на потребу в зниженні загального серцево-судинного ризику, досі бракує специфічного обгрунтування агресивного зниження маси тіла при ГКМП.

$\mathbb{E}$ описання клінічного випадку, в якому йдеться про зниження товщини стінки лівого шлуночка (ЛШ) у пацієнта з ГКМП у результаті суттєвої втрати ваги. Автори припускають, що лівошлуночкова гіпертрофія при ГКМП може модулюватися ожирінням [3].

Товщина стінки не єдина основна анатомічна ознака ГКМП, але вона може призводити до обструкції вихідного тракту ЛШ (ВТ ЛШ) і серцевої недостатності, а також вважається фактором ризику при оцінюванні профілю пацієнта щодо шлуночкових аритмій та $€$ фактором при прийнятті рішення щодо імплантації кардіовертера-дефібрилятора [2].

Canepa M., Sorensen L. та співавтори [1] у своєму дослідженні провели аналіз зв'язку ожиріння й клінічних симптомів, структури ЛШ та гемодинаміки в пацієнтів з ГКМП, висунувши гіпотезу, що ожиріння асоційоване з більш значною лівошлуночковою гіпертрофією і тому потенційно впливає на функцію ЛШ та фізичну витривалість. Автори показали, що пацієнти з ожирінням (IMT $\geq 30 \mathrm{kг} / \mathrm{M}^{2}, 36,4 \%$ хворих) частіше 
скаржились на задишку під час фізичних навантажень $(\mathrm{p}=0,04)$ та біль у грудях $(\mathrm{p}=0,002)$, а також більшу поширеність артеріальної гіпертензії $(\mathrm{p}=0,008)$. Товщина задньої стінки ЛШ (p=0,01), але не товщина міжлуночкової перегородки ( $\geq 00,21)$, були значно вищі в пацієнтів з ожирінням, що результує у вигляді збільшеного індексу маси ЛШ $(\mathrm{p}=0,03)$. Значущої різниці між систолічною і діастолічною функцією ЛШ не було виявлено, але ожиріння було асоційоване з більшим ударним викидом ЛШ ( $=0,03)$, індукованим градієнтом у ВТ ЛШ (p=0,045) і ризиком розвитку обструкції ВТ ЛШ під час навантаження (p = 0,035). Ожиріння також асоційоване зі зменшеним часом фізичних навантажень і функціональною здатністю, а IMT незалежно корелює зі зменшеною толерантністю до фізичних навантажень.

Доведено, що ожиріння в пацієнтів із ГКМП асоціюється з більшою масою ЛШ, тяжчими симптомами, нижчою толерантністю до фізичних навантажень і лабільною обструктивною гемодинамікою.

Однак численні дослідження продемонстрували, що пацієнти 3 надмірною вагою та ожирінням мають сприятливіший прогноз порівняно з тими, у кого нормальний IMT, після початку клінічних проявів серцево-судинного захворювання (СC3). Ці суперечливі знахідки були описані як «парадокс ожиріння». Від першого повідомлення більше 20 років тому і до сьогодні - у базі PubMed за запитом «obesity paradox» iндексуються понад 1300 статей.

Більше 20 років тому Ellis $\mathrm{S}$. та співавтори [4] висвітлили нижчий рівень госпітальної смертності в пацієнтів з коронарною хворобою серця та IMT 26-34

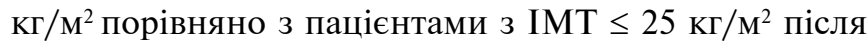
перкутанних втручань в одноцентровому дослідженні. У дослідженні реєстру British Cardiovascular Intervention Society, що включало 345192 пацієнти з 2005 по 2013 рік, хворі з ІМТ $\geq 25$ кг/м² мали значуще меншу смертність у короткостроковий (30 днів), середній (1 рік) і тривалий (5 років) терміни спостереження порівняно з хворими з нормальним IMT (18,5-24,9 кг $/ \mathrm{M}^{2}$ ) при виконанні перкутанного втручання [5]. У великому систематичному огляді, що включав 40 досліджень та 250152 пацієнти з коронарною хворобою серця, пацієнти з ожирінням не мають підвищеного ризику загальної смертності або серцево-судинної смертності при порівнянні з нормальним IMT. Серед пацієнтів з гострим коронарним синдромом хворі 3 надмірною вагою, ожирінням і тяжким ожирінням мають нижчу смертність порівняно з пацієнтами 3 нормальним IMT [6].

Stamou S. та співавтори [7] дослідили вплив IMT на клінічні результати після відкритих кардіохірургічних операцій і власне «парадокс ожиріння». Вони встановили, що пацієнти з надмірною вагою мали нижчу оперативну смертність ( $=0,031)$ порівняно $з$ пацієн- тами 3 нормальним IMT. Пацієнти з ожирінням мали подібний ризик оперативної смертності $(\mathrm{p}=0,47)$ порівняно з пацієнтами з нормальною вагою. Актуальна 5-річна виживаність була кращою для пацієнтів 3 надмірною вагою $(\mathrm{p}=0,002)$ і порівнянна для пацієнтів 3 ожирінням $(\mathrm{p}=0,49)$ порівняно з групою пацієнтів 3 нормальною вагою.

Проте Хia Ј. зі співавторами [8] у своєму дослідженні пояснюють та спростовують описаний «парадокс ожиріння». Існує декілька факторів, які мають бути прийняті до уваги під час інтерпретації результатів досліджень щодо оцінювання побічних серцево-судинних ефектів надмірної ваги. Вони включають наявність коморбідних і супутніх станів, критеріїв відбору пацієнтів для дослідження та використання IMT для класифікації надмірної маси.

Пацієнти з переважаючою серцево-судинною патологією зазвичай старші і мають тяжчі супутні захворювання, які самостійно можуть сприяти підвищенню смертності [9]. В аналізі 296535 учасників 3 біобанку Великобританії ожиріння було пов'язане $з$ підвищеним ризиком СС3, і цей зв'язок був ще сильнішим, коли з дослідження були виключені учасники із супутніми захворюваннями, що свідчить про те, що наявність коморбідних станів також може виступати як підтвердження взаємозв'язку між IMT та результатами [10].

Зниження IMT у пацієнтів із супутніми захворюваннями (зокрема ХОЗЛ, хронічні захворювання нирок, захворювання печінки, злоякісні новоутворення) може відображати тяжкість захворювання і загальну слабкість («frailty») та асоціюється з підвищеним ризиком СС3. Втрата ваги, що призводить до зниження IMT та обумовлена серцево-судинним захворюванням, може бути результатом підвищеного катаболізму або відсутності метаболічного резерву, на відміну від ожиріння. Це відображає зворотну причинність: втрата ваги є наслідком тяжкої хвороби, а не їі причиною [8].

У літературі зовсім відсутні дані щодо результатів лікування пацієнтів з ГКМП та ожирінням із використанням алкогольної септальної абляції (АСА), тому це дослідження є вкрай актуальним.

Мета. Визначити вплив ожиріння на результати лікування пацієнтів з ГКМП після алкогольної септальної абляції.

Матеріали та методи. За період з 2009 по 2018 рік серед 115 пацієнтів, яким було виконано ізольовану первинну процедуру АСА в НІССХ ім. М. М. Амосова, 53 (46,1 \%) пацієнти мали IMT більше 30, тобто супутнє захворювання - ожиріння різного ступеня тяжкості. Оскільки ожиріння є фактором, що підвищує ризик відкритих хірургічних втручань, слушно перевірити, чи впливає супутнє ожиріння на успішність процедури АСА й на виникнення додаткових ускладнень. Тому 


\section{Таблиця 1}

Загальна характеристика досліджуваної групи та групи порівняння

\begin{tabular}{lcc}
$\begin{array}{l}\text { Загальна кількість } \\
\text { пацієнтів }\end{array}$ & $\mathbf{5 3}$ & $\mathbf{6 2}$ \\
\hline Чоловіки & $25(47,16 \%)$ & $34(54,83 \%)$ \\
\hline Жінки & $28(52,83 \%)$ & $28(45,16 \%)$ \\
\hline $\begin{array}{l}\text { Середній вік } \\
\text { пацієнтів }\end{array}$ & $53,13 \pm 10,84$ & $42,75 \pm 16,9$ \\
\hline Вік, роки & & \\
До 18 років & 0 & 4 \\
18-35 років & 3 & 23 \\
36-60 років & 36 & 26 \\
60-74 років & 13 & 1 \\
75 років і старше & 1 & $25,82 \pm 3,36$ \\
\hline Індекс маси тіла & $34,4 \pm 4,29$ & 0 \\
\hline Ожиріння І ст. & $37(69,81 \%)$ & 0 \\
\hline Ожиріння ІІ ст. & $10(18,87 \%)$ & 0 \\
\hline Ожиріння ІІІ ст. & $6(11,32 \%)$ &
\end{tabular}

53 пацієнти з ГКМП, які мали ожиріння, увійшли у 1-у групу, а 62 пацієнти з ГКМП без ожиріння склали 2-у групу (таблиця 1).

Результати роботи. Пацієнти 1-ї групи були більш симптоматичними, на відміну від пацієнтів 2-ї групи. У них достовірно частіше відзначали задишку, набряки на нижніх кінцівках, загальну слабкість та запаморочення.

У пацієнтів з ГКМП та ожирінням після АСА спостерігалося значне покращення функціонального класу (ФК) за NYHA. Так, 1 пацієнт, який перебував у IV ФК, змінив свій функціональний клас на III; 27 пацієнтів, які перебували в III ФК, змінили його на II ФК; а 8 пацієнтів, які мали II ФК, покращили свій функціональний клас до I (таблиця 2).

\section{Таблиця 3}

Біохімічні маркери пошкодження міокарда в динаміці

\section{Таблиця 2}

Динаміка зміни ФК за NYHA після проведеної $A C A$ в пацієнтів з ГКМП та ожирінням

\begin{tabular}{|c|c|c|c|}
\hline $\begin{array}{l}\text { ФК за } \\
\text { NYHA }\end{array}$ & $\begin{array}{c}\text { Кількість } \\
\text { пацієнтів до } \\
\text { процедури } \\
\text { АСА з ГКМП та } \\
\text { ожирінням }\end{array}$ & $\begin{array}{c}\text { Кількість } \\
\text { пацієнтів, які } \\
\text { змінили свій ФК } \\
\text { за NYHA }\end{array}$ & $\begin{array}{c}\text { Кількість } \\
\text { пацієнтів після } \\
\text { процедури } \\
\text { АСА з ГКМП та } \\
\text { ожирінням }\end{array}$ \\
\hline 1 & 0 & $8 \longrightarrow$ & 8 \\
\hline II & 18 & $\longrightarrow$ & 37 \\
\hline III & 34 & $\longrightarrow$ & 8 \\
\hline IV & 1 & & 0 \\
\hline
\end{tabular}

У пацієнтів обох груп у 1-у добу після процедури спостерігалося підвищення вище норми всіх досліджуваних біологічних маркерів пошкодження міокарда, яке статистично не відрізнялося між двома групами (р $\geq 0,05)$. На 3-ю добу досліджувані біохімічні маркери наближалися до норми або вже перебували в межах норми та статистично не відрізнялися між двома групами. На 7-у добу в обох групах спостерігалася нормалізація рівнів усіх досліджуваних ензимів (таблиця 3).

За анатомічними та гемодинамічними показниками, які досліджувались при ЕхоКГ, обидві групи статистично не відрізнялись, за винятком товщини задньої стінки ЛШ, яка була статистично більшою в групі пацієнтів з ГКМП та ожирінням. Після проведення процедури АСА ці показники між групами були також статистично рівними, окрім задньої стінки ЛШ, товщина якої залишилася більшою в пацієнтів з ГКМП та ожирінням. Але в 1-й групі градієнт систолічного тиску у вихідному тракті ЛШ (ВТ ЛШ) після процедури знизився з 90,79 $\pm 22,57$ до $42,66 \pm 24,94$ мм рт. ст., а в 2-й групі - з 93,27 $\pm 26,88$ до $43 \pm 25,39$ мм рт. ст. Мітральна регургітація в обох групах зменшилася від по-

\begin{tabular}{|c|c|c|c|c|c|c|c|c|c|c|}
\hline \multirow[b]{2}{*}{ Ферменти } & \multirow[b]{2}{*}{ Норма } & \multicolumn{2}{|c|}{ 1-а доба після процедури } & \multirow[b]{2}{*}{ P-value } & \multicolumn{2}{|c|}{$\begin{array}{l}\text { 3-я доба після процедури } \\
\text { (n = 115) }\end{array}$} & \multirow[b]{2}{*}{ P-value } & \multicolumn{2}{|c|}{$\begin{array}{l}\text { 7-а доба після процедури } \\
\text { (n = 115) }\end{array}$} & \multirow[b]{2}{*}{ P-value } \\
\hline & & $\begin{array}{c}\text { 1-a група, } \\
n=53\end{array}$ & $\begin{array}{c}\text { 2-a група, } \\
n=62\end{array}$ & & $\begin{array}{c}\text { 1-a група, } \\
n=53\end{array}$ & $\begin{array}{c}\text { 2-a група, } \\
n=62\end{array}$ & & $\begin{array}{c}\text { 1-a група, } \\
n=53\end{array}$ & $\begin{array}{c}\text { 2-a група, } \\
n=62\end{array}$ & \\
\hline $\begin{array}{l}\text { МВ-фракція } \\
\text { креатинкінази }\end{array}$ & $\leqslant 24$ & $189,6 \pm 120,06$ & $186,57 \pm 124,89$ & 0,895 & $35,73 \pm 52,59$ & $43,37 \pm 45,53$ & 0,411 & $19,77 \pm 14,97$ & $17,78 \pm 7,89$ & 0,386 \\
\hline $\begin{array}{l}\text { Загальна } \\
\text { креатинкіназа }\end{array}$ & $\leqslant 180$ & $1103,44 \pm 627,08$ & $1136,62 \pm 618,99$ & 0,776 & $295,85 \pm 360,65$ & $\begin{array}{c}321,91 \pm \\
304,69\end{array}$ & 0,679 & $\begin{array}{c}120,47 \pm \\
77,62\end{array}$ & $104,5 \pm 34,09$ & 0,168 \\
\hline $\begin{array}{l}\text { Аланінаміно- } \\
\text { трасфераза }\end{array}$ & $\leqslant 42$ & $47,09 \pm 20,77$ & $44,19 \pm 18,24$ & 0,433 & $39,65 \pm 26,5$ & $42,63 \pm 20$ & 0,503 & $42,5 \pm 35,19$ & $38,23 \pm 27,65$ & 0,477 \\
\hline $\begin{array}{l}\text { Аспартатаміно- } \\
\text { грансфераза }\end{array}$ & $\leqslant 30$ & $161,79 \pm 92,84$ & $176,55 \pm 102,42$ & 0,420 & $47,9 \pm 17,17$ & $49,24 \pm 12,14$ & 0,650 & $34,47 \pm 19,97$ & $32,25 \pm 14,19$ & 0,501 \\
\hline $\begin{array}{l}\text { дктатде- } \\
\text { дрогеназа }\end{array}$ & $\leqslant 420$ & $543,41 \pm 163,93$ & $505,59 \pm 199,52$ & 0,267 & $458,85 \pm 153,66$ & $\begin{array}{c}521,23 \pm \\
208,94\end{array}$ & 0,068 & $\begin{array}{l}378,03 \pm \\
136,55\end{array}$ & $351,92 \pm 94,47$ & 0,243 \\
\hline
\end{tabular}


Таблиця 4

Гемодинамічні та анатомічні показники до та після процедури АCA

\begin{tabular}{|c|c|c|c|c|c|c|}
\hline Показники & $\begin{array}{c}\text { 1-а група до } \\
\text { процедури АСА }\end{array}$ & $\begin{array}{c}\text { 2-а група до } \\
\text { процедури ACA }\end{array}$ & P value & $\begin{array}{l}\text { 1-а група після } \\
\text { процедури АСА }\end{array}$ & $\begin{array}{l}\text { 2-а група після } \\
\text { процедури АСА }\end{array}$ & P value \\
\hline $\begin{array}{l}\text { Градієнт систолічного } \\
\text { тиску, мм рт. ст. }\end{array}$ & $90,79 \pm 22,57$ & $93,27 \pm 26,88$ & 0,592 & $42,66 \pm 24,94$ & $43 \pm 25,39$ & 0,943 \\
\hline Мітральна регургітація, + & $1,83 \pm 0,5$ & $1,83 \pm 0,42$ & 0,991 & $1,36 \pm 0,42$ & $1,39 \pm 0,48$ & 0,765 \\
\hline $\begin{array}{l}\text { Товщина міжшлуночкової } \\
\text { перегородки, см }\end{array}$ & $2,44 \pm 0,34$ & $2,39 \pm 0,46$ & 0,497 & $1,92 \pm 0,33$ & $2,03 \pm 0,63$ & 0,244 \\
\hline $\begin{array}{l}\text { Товщина задньої стінки } \\
\text { ЛШ, см }\end{array}$ & $1,34 \pm 0,33$ & $1,23 \pm 0,25$ & 0,043 & $1,45 \pm 0,35$ & $1,08 \pm 0,21$ & 0,000 \\
\hline КДІ & $47,36 \pm 9,84$ & $46,3 \pm 7,76$ & 0,526 & $48,04 \pm 7,31$ & $49,78 \pm 9,41$ & 0,268 \\
\hline $\mathrm{KCl}$ & $17,94 \pm 4,85$ & $16,49 \pm 4,26$ & 0,095 & $18,59 \pm 3,61$ & $18,16 \pm 4,17$ & 0,553 \\
\hline $\mathrm{yl}$ & $25,21 \pm 11,38$ & $27,96 \pm 10,3$ & 0,179 & $24,35 \pm 11,86$ & $23,42 \pm 13,55$ & 0,696 \\
\hline Фракція викиду, \% & $62,85 \pm 6,75$ & $63,47 \pm 5,59$ & 0,610 & $61,30 \pm 4,61$ & $63,20 \pm 4,43$ & 0,026 \\
\hline $\begin{array}{l}\text { Розмір лівого передсердя, } \\
\text { см }\end{array}$ & $4,90 \pm 0,45$ & $4,59 \pm 0,61$ & 0,002 & $4,84 \pm 0,42$ & $4,57 \pm 0,63$ & 0,001 \\
\hline
\end{tabular}

Примітка. КДІ - кінцевий діастолічний індекс; КСІ - кінцевий систолічний індекс; УІ - ударний індекс.

мірної до незначної. Інші анатомічні та гемодинамічні показники до та після процедури в обох групах достовірно не змінилися (таблиця 4).

Летальність у безпосередньому періоді спостереження в 1-й групі становила $1,9 \%$ (1 пацієнт), у 2-й групі - 1,6\% (1 пацієнт) та статистично не відрізнялася в обох групах.

\section{Висновки}

1. Ожиріння є фактором ризику розвитку серцево-судинних захворювань, а також здатне впливати на результати кардіохірургічних втручань.

2. Алкогольна септальна абляція в пацієнтів із ГКМП та ожирінням у більшості випадків здатна покращити клінічний перебіг захворювання (зменшити симптоми, покращити функціональний клас).

3. Ожиріння у пацієнтів з ГКМП не погіршує гемодинамічні результати після алкогольної септальної абляції та не підвищує летальність у безпосередньому періоді спостережень.

4. Алкогольна септальна абляція є методом вибору в пацієнтів з ГКМП та ожирінням.

\section{Список використаних джерел References}

1. Canepa M, Sorensen L, Pozios I, Dimaano V, Luo H, Pinheiro A, et al. Comparison of Clinical Presentation, Left Ventricular Morphology, Hemodynamics, and Exercise Tolerance in Obese Versus Nonobese Patients With Hypertrophic Cardiomyopathy. Am J Cardiol. 2013 Oct 15;112(8):1182-9 https://doi.org/10.1016/j. amjcard.2013.05.070

2. Gersh B, Maron B, Bonow R, Dearani J, Fifer M, Link $\mathrm{M}$, et al. 2011 ACCF/AHA Guideline for the Diagnosis and Treatment of Hypertrophic Cardiomyopathy. J Am
Coll Cardiol. 2011 Dec 13;58(25):e212-60. https://doi. org/10.1016/j.jacc.2011.06.011

3. Uwaifo G, Fallon E, Calis K, Drinkard B, McDuffie J, Yanovski J. Improvement in Hypertrophic Cardiomyopathy after Significant Weight Loss: Case Report. South Med J. 2003 Jun;96(6):626-31. https://doi.org/10.1097/01. SMJ.0000053254.23595.14

4. Ellis S, Elliott J, Horrigan M, Raymond R, Howell G. Low-Normal or Excessive Body Mass Index: Newly Identified and Powerful Risk Factors for Death and Other Complications With Percutaneous Coronary Intervention. Am J Cardiol. 1996 Sep 15;78(6):642-6. https://doi. org/10.1016/S0002-9149(96)00386-4

5. Holroyd E, Sirker A, Kwok C, Kontopantelis E, Ludman P, De Belder, et al. The Relationship of Body Mass Index to Percutaneous Coronary Intervention Outcomes: Does the Obesity Paradox Exist in Contemporary Percutaneous Coronary Intervention Cohorts? Insights From the British Cardiovascular Intervention Society Registry. JACC Cardiovasc Interv. 2017 Jul 10;10(13):1283-92. https:// doi.org/10.1016/j.jcin.2017.03.013

6. Niedziela J, Hudzik B, Niedziela N, Gąsior M, Gierlotka $\mathbf{M}$, Wasilewski $\mathbf{J}$, et al. The obesity paradox in acute coronary syndrome: a meta-analysis. Eur J Epidemiol. 2014 Nov;29(11):801-12. https://doi.org/10.1007/s10654-0149961-9

7. Stamou S, Nussbaum M, Stiegel R, Reames M, Skipper E, Robicsek F., et al. Effect of Body Mass Index on Outcomes After Cardiac Surgery: Is There an Obesity Paradox? Ann Thorac Surg. 2011 Jan;91(1):42-7. https://doi. org/10.1016/j.athoracsur.2010.08.047

8. Xia J, Lloyd-Jones D, Khan S. Association of body mass index with mortality in cardiovascular disease: New insights into the obesity paradox from multiple perspectives. Trends Cardiovasc Med. 2019 May;29(4):220-5. https://doi. org/10.1016/j.tcm.2018.08.006 
9. Mensah G, Brown D. An Overview Of Cardiovascular Disease Burden In The United States. Health Aff (Millwood). 2007 Jan-Feb;26(1):38-48. https://doi. org/10.1377/hlthaff.26.1.38

10. Iliodromiti S, Celis-Morales C, Lyall D, Anderson J, Gray S, Mackay D, et al. The impact of confounding on the associations of different adiposity measures with the incidence of cardiovascular disease: a cohort study of 296535 adults of white European descent. European Heart Journal. 2018 May;39(17):1514-20. https://doi. org/10.1093/eurheartj/ehy057

\title{
Alcohol Septal Ablation in Patients with Hypertrophic Cardiomyopathy and Obesity
}

\author{
Rudenko K. V. ${ }^{1}$, Nevmerzhytska L. O. ${ }^{1}$, Dudnyk O. Yu. ${ }^{1}$, Fanta S. M. ${ }^{1}$, Malaniuk V. I. ${ }^{2}$, Lazoryshynets V. V. ${ }^{1}$
}

${ }^{1}$ National M. M. Amosov Institute of Cardiovascular Surgery of the National Academy of Medical Sciences of Ukraine, Kyiv, Ukraine

\section{${ }^{2}$ Main Military Medical Clinical Center «MMCH», Kyiv, Ukraine}

Abstract. The article represents a literature review and analysis of actual experience of the treatment of patients with hypertrophic cardiomyopathy (HCM) and obesity. Obesity is a significant risk factor for the development and course of cardiovascular diseases. There are a lot of articles describing the "obesity paradox" as more favorable prognosis in patients with overweight and obesity compared to those with normal BMI. It refers to a lower level of hospital mortality and mortality in long-term follow-up after percutaneous interventions and open heart surgery. However, these findings are not reliable, since they do not take into account the presence of comorbid and concomitant conditions in patients, have specific criteria for patient selection for the study and use only BMI for the classification of overweight. This reflects the reciprocal causality: weight loss is the result of a serious illness, not its cause.

It has been shown that obesity in patients with HCM is associated with a higher left ventricle myocardial mass, more severe symptoms, lower exercise tolerance, and labile obstructive hemodynamics. We studied the effect of obesity on the results of alcohol septal ablation (ASA) in patients with HCM.

Obesity is an important risk factor for the development of cardiovascular diseases and is also able to affect cardiac surgery risks. It has been shown that ASA in patients with HCM and obesity in most cases may improve clinical course of the disease (symptoms and functional class improvement). Also, there is no difference in the anatomical and hemodynamic results, mortality rate in obese patients and those with normal BMI in the immediate follow-up. ASA is recommended as a first-line method in patients with HCM and obesity.

Keywords: hypertrophic cardiomyopathy, obesity, obesity paradox, alcohol septal ablation.

Стаття надійшла в редакцію 16.04.2019 р. 